\title{
ANALYSIS OF SPECIES IN MEAT PRODUCTS IN BANDUNG CITY USING MULTIPLEX PCR
}

\author{
Yelliantty \\ Ira Endah Rohima \\ Department of Food Technology, Faculty of Engineering, Pasundan University, Bandung, Indonesia \\ E-mail : yelliantty@unpas.ac.id
}

\begin{abstract}
Cases concerning the substitution of meat raw material also occur in Indonesia and are quite common. Therefore, careful monitoring and control that needs to be done on the meat products. Screening or sampling products on the market should be conducted periodically to ensure the safety of consumers and society in general. Such screening should be done accurately. This study aimed to analyze the composition of meat in processed products in traditional markets in Bandung using PCR method. This study was using four specific primers to detect four different species. Screening is done on samples of meatballs from several markets. The results showed the presence of several samples that contain meat of some species. based it can be concluded that the substitution of raw materials processed meat products also occurs in the traditional market in the city of Bandung, and the PCR method referred to can be used as the basis for the development of detection methods of food security in Indonesia.
\end{abstract}

Keyword: meat, multiplex PCR, species identification

\section{Introduction}

Meat is one source of high protein for humans. Currently a lot of food or any processed food made from raw meat. Some of the processed foods that have been widely consumed in Indonesia include nuggets, meatballs, sausages, bacon, corned beef, burgers, and others. Foodstuff processed based on meat is a type of food that much in demand by the people of Indonesia in addition to fresh meat. This is because the processed meat-based foods have a variety of flavors and forms of interest, relatively long shelf time, and relatively cheaper than the price of fresh meat, even some parties claimed that this processed meat-based food can also meet the nutritional needs well.[1,2]

Manufacturers of food and processed meat products have been produced by many parties. From the level of large producers (factories) to home industries. In products produced by large companies generally have high quality, both on product quality and packaging. In addition, products produced by large companies are also indirectly accompanied by product quality assurance given to the public (consumers). This quality assurance is indicated by the label or description on the packaging of the content or composition contained in the product.[1, 3]

Some studies in the world show the possibility of inconsistency between the composition on the label compared with the real composition contained in the product. Some cases that have been found include the mixing or substitution of raw materials of meat from other animals. One of them is the use of fanged animal meat such as dogs or rodents such as mice on processed meatballs or sausage foods. In addition, there is also mixing or substitution of chicken or fish in processed food products of beef meatballs. [3, 4]
The substitution or mixing of the meat raw material is a serious problem. This can be detrimental to consumers both in terms of economy and even health. Mixing of meat raw materials that do not match the ones on the labels indicates the irresponsible actions of the producers, and the consumer economically incurs losses for paying for inappropriate products. Losses in the health sector can also be experienced by consumers, because the mixing of substitutes by unhealthy raw materials can be a source of disease for consumers. [1, 35]

The case of substitution of meat raw materials also occurs in Indonesia and is quite common. Some recent issues indicate the substitution of beef with mutton meat to make meatballs, for economic reasons. In addition, there is also a substitution of beef with pork to enhance the taste. But in Indonesia with the majority of Moslems, then it should be disclosed clearly because it involves halal.[6] Therefore, careful monitoring and control should be undertaken on these meat products. Screening and sampling of existing products on the market need to be done periodically to ensure the safety of consumers and the public at large. With the data on product screening, then we can get information about the picture of product safety circulating in the community.

Qualitative analysis to know the composition of a product is very diverse. The simplest analysis or identification is the organoleptic approach. However, this method is very difficult to perform and requires excellent expertise. Identification with organoleptics will be very difficult when analyzing samples of processed meat products. Therefore, other approaches have been made at the protein and molecular levels. So far, the determination of the composition of meat food 
that has been widely used is a protein-based method. But the method is costly and relatively difficult to do. Another approach is to use the PCR technique.[3, 7, 8] The PCR technique can be used to analyze a biological food such as meat. This technique has a good sensitivity in detecting the existence of very small and small samples.[6,8] In addition, the cost required to perform the technique is relatively cheaper than the protein. The process is relatively more practical than protein-based methods. Therefore, in this research will be analyzed qualitatively using PCR method to detect and confirm the composition of raw materials of meat in meat products and processed products produced by large producers and marketed in the city of Bandung.

\section{Materials and Methods} Samples

Processed Meat products such as beef sausage, chicken sausage, corned beef, beef meatballs, chicken meatballs and fish meatballs. Processed meat products without brand and marketed in Bandung Raya traditional market.

Isolation DNA

The DNA purification protocol uses a kit of Promega DNA Wizard.

Polymerase Chain Reaction

Ruminants

The primer sequences used were as follows.[3]

Forward: 5'-GAA AGG ACA AGA GAA ATA AGG-3' Reverse: 5'-TAG CGG GTC GTA GTG GTT CT-3' Swine

Forward: 5'-CTA CAT AAG AAT ATC CAC CAC-3' Reverse: 5'-ACA TTG TGG GAT CTT CTA GGT-3' Fish

Forward: 5'-TAA GAG GGC CGG TAA AAC TC-3' Reverse: 5'-GTG GGG TAT CTA ATC CCA G-3' Poultry

Forward: 5'- GGG CTA TTG AGC TCA CTG TT-3' Reverse: 5'-TGA GAA CTA CGA GCA CAA AC-3'

\section{Result and Discussion}

The results of the analysis indicate that most of the foodstuff processed samples contain basic raw materials in accordance with the information given by the seller regarding the products sold. These data indicate that the processed meat food in Bandung Raya area has good quality seen from the aspect of the suitability of the raw materials with the resulting processed products. However, there are some samples showing results that still require further confirmation, namely corned beef and beef cattle products. The PCR results of both samples showed the tendency of two different species. The possibility in the sample is substitution or addition of other types of meat that is poultry as raw material.

Processed beef products have high potential for fraud of raw materials. Starting from substitution to raw material combination. This is due to economic factors, where the price of beef is more expensive than other types of meat. To anticipate the selling price of processed beef products are usually done substitution or combinationCombining beef with other types of meat would not actually be considered a fraud if from the beginning the seller explained the composition or content of meat in its product.[9-11]

PCR analysis results indicate conformity with the merchant's description and the label affixed to all products. However, there are some products that are undetectable and less clear the results of the analysis. The results of undetectable analysis are mostly found in samples of beef sausage, chicken sausage, and chicken meatball. This can be due to poor quality of DNA isolation. The isolation results depend on DNA isolation methods that may be less suitable or less optimal for a particular product.

Sample factors can influence the success or quality of isolated DNA. The sample matrix is the most important constraint in this study. Although DNA isolation can be done, the quality of DNA is not always the same in each sample. The results of the study in Table 1 show that the sample of corned beef from all sample points can be analyzed by PCR, whereas in the sample of sausage there is an unsuccessful examination. This suggests that the sample matrix can indeed affect the success of DNA isolation. Therefore, there is still a need for separate research to optimize the DNA isolation protocol of a particular sample matrix.

Table 1. Analysis of Sample Species

\begin{tabular}{|c|c|c|c|c|c|c|}
\hline \multirow{3}{*}{$\begin{array}{l}\text { Prod } \\
\text { ucts }\end{array}$} & \multicolumn{6}{|c|}{ Traditional Market } \\
\hline & \multicolumn{2}{|c|}{ Market-1 } & \multicolumn{2}{|c|}{ Market-2 } & \multicolumn{2}{|c|}{ Market-3 } \\
\hline & $\begin{array}{c}\text { Merc } \\
\text { hant- } \\
\text { A }\end{array}$ & $\begin{array}{c}\text { Merc } \\
\text { hant- } \\
\text { B }\end{array}$ & $\begin{array}{c}\text { Merc } \\
\text { hant- } \\
\text { A }\end{array}$ & $\begin{array}{c}\text { Merc } \\
\text { hant- } \\
\text { B }\end{array}$ & $\begin{array}{c}\text { Merc } \\
\text { hant- } \\
\text { A }\end{array}$ & $\begin{array}{c}\text { Merc } \\
\text { hant- } \\
\text { B }\end{array}$ \\
\hline $\begin{array}{l}\text { Beef } \\
\text { Saus } \\
\text { age }\end{array}$ & $\sqrt{ }$ & $*$ & $\sqrt{ }$ & $\sqrt{ }$ & $*$ & $\sqrt{ }$ \\
\hline $\begin{array}{l}\text { Chic } \\
\text { ken } \\
\text { Saus } \\
\text { age }\end{array}$ & $\sqrt{ }$ & $*$ & $*$ & $\sqrt{ }$ & $\sqrt{ }$ & $\sqrt{ }$ \\
\hline $\begin{array}{l}\text { Beef } \\
\text { Corn } \\
\text { ed }\end{array}$ & $\sqrt{ }$ & $\sqrt{ }$ & $* *$ & $\sqrt{ }$ & $\sqrt{ }$ & $\sqrt{ }$ \\
\hline $\begin{array}{l}\text { Beef } \\
\text { Mea } \\
\text { tball }\end{array}$ & $\sqrt{ }$ & $*$ & $\sqrt{ }$ & $* *$ & $\sqrt{ }$ & $\sqrt{ }$ \\
\hline $\begin{array}{l}\text { Chic } \\
\text { ken } \\
\text { Mea } \\
\text { tball }\end{array}$ & $\sqrt{ }$ & $\sqrt{ }$ & $*$ & $\sqrt{ }$ & $*$ & $*$ \\
\hline $\begin{array}{l}\text { Fish } \\
\text { ball }\end{array}$ & $\sqrt{ }$ & $\sqrt{ }$ & $*$ & $\sqrt{ }$ & $\sqrt{ }$ & $\sqrt{ }$ \\
\hline
\end{tabular}

Notes: $\left.\sqrt{\text { correct; }}{ }^{*}\right)$ Undetected; $\left.* *\right)$ Need confirmation 
The amount of beef content in sausage and corned beef is different. In addition, the texture and size of the meat components in each product are different. In sausage, the meat component is very homogeneous compared to corned beef. In beef corned, the size of the meat component is still larger and the muscle fibers of the meat can still be seen organoleptically. This indirectly indicates that cell condition as well as meat tissue in corned beef samples still survive compared with sausages. So that can get more DNA samples with good condition. Therefore, the method of DNA isolation still needs to be optimized for some other types of processed meat products.

The results of this study can not describe the incidence of substitution of raw materials and fraud that occurred in Bandung Raya exactly. The number of samples taken is still very minimal and does not meet statistically requirements to be representative of the population as a whole. However, the data obtained in this study can be preliminary data for the development of supervision and control methods of processed products based on molecular meat.

Based on the above explanation, this study still has a deficiency of the data obtained are still qualitative and the number of samples that are still not sufficient to be used as data representing the population. In addition, in this study still needed further research related to optimization of protocol analysis and research with a larger sample size.

Based on the results of this study it can be concluded that multiple PCR method can be used to analyze the suitability of raw materials of processed meat food sold in Bandung. Meat raw materials used in processed products in accordance with the description of products sold.

\section{Bibliography}

1. Ghovvati, S., et al., Fraud identification in industrial meat products by multiplex PCR assay. Food Control, 2009. 20(8): p. 696-699.

2. Biswas, A.K., et al., Dietary fibers as functional ingredients in meat products and their role in human health International Journal of Livestock Production, 2011. 2(4): p. 45-54.

3. Sakalar, E. and M.F. Abasiyanik, Qualitative analysis of meat and meat products by multiplex polymerase chain reaction (PCR) technique. African Journal of Biotechnology, 2011. 10(46): p. 9379-9386.

4. Johnson, R., Food fraud and "Economically motivated adulteration" of food and food ingredients. Congressional Research Service. 2014. 1-40.

5. Hoekstra, A.Y., The hidden water resource use behind meat and dairy. Animal Frontier, 2012. 2(2): p. 3-8.

6. Zahran, D. and S. Hagag, Use of molecular biology techniques in the detection of fraud meat in the Egyptian market. African Journal of Biotechnology, 2015. 14(5): p. 360-364.
7. Doosti, A., P. Ghasemi Dehkordi, and E. Rahimi, Molecular assay to fraud identification of meat products. Journal of Food Science and Technology, 2014. 51(1): p. 148-152.

8. Aida, A.A., et al., Analysis of raw meats and fats of pigs using polymerase chain reaction for Halal authentication. Meat Science, 2005. 69(1): p. 47-52.

9. Rezazadeh, T., K. Aghaiypour, and Z. Heidari, Significance of authenticity in meat and meat products in Iran. Iranian Journal of Health, Safety and Environment, 2014. 1(2): p. 83-88.

10. Kitpipit, T., K. Sittichan, and P. Thanakiatkrai, Are these food products fraudulent? Rapid and noveltriplexdirect PCR assay for meat identification. Forensic Science International: Genetics Supplement Series, 2013. 4: p. e33-e34.

11. Yacoub, H.A. and M.A. Sadek, Identification of fraud (with pig stuffs) in chicken-processed meat through information of mitochondrial cytochrome $b$. Mitochondrial DNA Part A, 2017. 28(6): p. 855-859. 